\title{
Treating (Recurrent) Vulvovaginal Candidiasis with Medical-Grade Honey-Concepts and Practical Considerations
}

\author{
Senna J. J. M. van Riel ${ }^{1}$, Celine M. J. G. Lardenoije ${ }^{1}$, Guy J. Oudhuis ${ }^{2}$ and Niels A. J. Cremers ${ }^{3, *(1)}$ \\ 1 Department of Gynecology and Obstetrics, Maastricht University Medical Centre, \\ 6202 AZ Maastricht, The Netherlands; sjjmvanriel@gmail.com (S.J.J.M.v.R.); \\ celine.lardenoije@mumc.nl (C.M.J.G.L.) \\ 2 Department of Medical Microbiology, Maastricht University Medical Centre, NUTRIM School of Nutrition \\ and Translational Research in Metabolism, Faculty of Health, Medicine and Life Sciences, \\ Maastricht University, 6202 AZ Maastricht, The Netherlands; g.oudhuis@mumc.nl \\ 3 Triticum Exploitatie B.V., Sleperweg 44, 6222 NK Maastricht, The Netherlands \\ * Correspondence: niels@mesitran.com; Tel.: +31-43-325-1773
}

Citation: van Riel, S.J.J.M. Lardenoije, C.M.J.G.; Oudhuis, G.J.; Cremers, N.A.J. Treating (Recurrent) Vulvovaginal Candidiasis with Medical-Grade Honey-Concepts and Practical Considerations. J. Fungi 2021, 7, 664. https://doi.org/ $10.3390 /$ jof7080664

Academic Editor: David S. Perlin

Received: 31 May 2021

Accepted: 13 August 2021

Published: 16 August 2021

Publisher's Note: MDPI stays neutral with regard to jurisdictional claims in published maps and institutional affiliations.

Copyright: (c) 2021 by the authors. Licensee MDPI, Basel, Switzerland. This article is an open access article distributed under the terms and conditions of the Creative Commons Attribution (CC BY) license (https:/ / creativecommons.org/licenses/by/ $4.0 /)$.

\begin{abstract}
Recurrent vulvovaginal candidiasis (RVVC) is a relapsing vaginal fungal infection caused by Candida species. The prevalence varies among age populations and can be as high as $9 \%$. Treatment options are limited, and in $57 \%$ of the cases, relapses occur within six months after fluconazole maintenance therapy, which is the current standard of care. The pathogenesis of RVVC is multifactorial, and recent studies have demonstrated that the vaginal microenvironment and activity of the immune system have a strong influence on the disease. Medical-grade honey (MGH) has protective, antimicrobial, and immunomodulatory activity and forms a putative alternative treatment. Clinical trials have demonstrated that honey can benefit the treatment of bacterial and Candida-mediated vaginal infections. We postulate that MGH will actively fight ongoing infections; eradicate biofilms; and modulate the vaginal microenvironment by its anti-inflammatory, antioxidative, and immunomodulatory properties, and subsequently may decrease the number of relapses when compared to fluconazole. The MGH formulation L-Mesitran Soft has stronger antimicrobial activity against various Candida species than its raw honey. In advance of a planned randomized controlled clinical trial, we present the setup of a study comparing L-Mesitran Soft with fluconazole and its practical considerations.
\end{abstract}

Keywords: recurrent vulvovaginal candidiasis; medical-grade honey; fluconazole; alternative treatment; micro-environment modulation

\section{Introduction}

Vulvovaginal candidiasis (VVC) is a vaginal fungal infection confirmed to be caused by Candida species, in most cases Candida albicans [1]. A total of 75\% of women develop vulvovaginal candidiasis at least once in their life [2]. The symptoms related to vulvovaginal candidiasis are pruritus, soreness, irritation, dyspareunia, vaginal discharge, and discomfort. Clinical signs are exemplified by vulva erythema, edema, excoriation, and fissure formation, together with introital and vaginal erythema [1,3]. A non-malodorous clumpy white discharge is suggestive of VVC but is extremely nonspecific [1]. Women also report loss of confidence and self-esteem, inability to carry on with their normal physical activities, and difficulties with their sexual life and intimate relationships [2]. It also has a profound effect on the quality of life of affected women with additional systemic symptoms including depression and anxiety [1]. The definition of recurrent vulvovaginal candidiasis (RVVC) is at least three symptomatic episodes in the last 12 months [1]. RVVC affects about 138 million women per year worldwide (range of 103-172 million), with a global annual prevalence of 3871 per 100,000 women [2]. The highest prevalence (9\%) is seen in women of an age between 25 and 34 years old. It is estimated that the population of women with recurrent vulvovaginal candidiasis will increase to almost 158 million in 2030 [2]. 
RVVC is a multifactorial disease whose symptoms are governed by the interaction between Candida (species and virulence factors), the Lactobacilli population, the microenvironment (inflammatory status, oxidative stress, estrogen), and the host (immune status, behavioral factors, genetic factors). A disbalance in any of these factors may induce RVVC [4].

VVC is according to the Clinical Practice Guidelines treated with topical or oral antifungals, of which azoles (miconazole, clotrimazole, and fluconazole) are the most commonly prescribed [5]. Notably, there is an increase in resistance of Candida species towards antifungal agents, causing multidrug resistance to emerge, while the long-term efficacy of antifungal agents is limited [3,6,7]. Therefore, an urgent need for alternative or complementary therapies to effectively treat RVVC and prevent it from recurrence is needed. It is important to know more about the etiology of RVVC, the different treatment options, and their efficacy to understand how novel therapies could improve the clinical outcome and quality of life.

\section{Diagnosis of RVVC}

RVVC is often overdiagnosed or misdiagnosed when the diagnosis is only based on clinical symptoms, which are non-specific. Laboratory testing is necessary to confirm the diagnosis of VVC, because self-diagnosis based on symptoms has an accuracy rate of only $28 \%$ for Candida albicans in self-treating women, making over-the-counter (OTC) antifungals often ineffective $[5,8,9]$. The golden standard for the diagnosis of VVC is by culturing the cells. It is also possible to use microscopy to identify yeast cells and hyphae. Gram staining of vaginal discharge mixed with potassium hydroxide $(\mathrm{KOH})$ is used to distinguish Candida yeast cells and hyphae, which is relevant to the stage of the pathogenesis. The $\mathrm{pH}$ of the vaginal discharge is also an important indicator and normally stays within a range of 4.0-4.5. A pH above 4.7 is indicative of other infections such as bacterial vaginosis, trichomoniasis, or mixed infections $[1,10,11]$. For further differentiation between Candida species, additional culturing is needed, e.g., with chromogenic agar or Sabourad's dextrose agar. However, culturing is not the most selective procedure, and molecular methods such as sequencing of the internal transcribed spacer (ITS sequencing) or matrix-assisted laser desorption ionization time-of-flight mass spectrometry (MALDI-ToF MS) are needed to identify the specific species [12,13]. This is especially relevant in the case of RVVC, in which non-albicans species (NAC) are becoming more prevalent. Similarly, susceptibility testing may be of adjuvant need in RVVC, as these infections are more resistant to antifungal agents [11].

\section{Pathogenesis of RVVC}

In approximately $90 \%$ of VVC episodes, Candida albicans is the causative agent [14]. However, NAC species can also cause VVC, such as Candida glabrata, Candida krusei, Candida parapsilosis, Candida tropicalis, and Candida dubliniensis, with Candida glabrata predominating [15].

Asymptomatic colonization of Candida species may persist for years because yeasts can live in symbiosis with vaginal microbiota and are tolerated by the immune system $[1,16]$. Acute symptomatic VVC causes a breakdown in the symbiotic relationship and is caused by an overgrowth of Candida or alteration in the host protective defense mechanisms [1]. Often, there is an underlying cause of the imbalance (e.g., antibiotic therapy) that allows Candida species to overgrow $[1,2,4]$. There seems to be a local mucosal overreaction caused by an exaggerated inflammatory response responsible for vulvovaginal symptoms $[1,4]$. This response can be triggered by host pattern recognition receptors (PRP) interacting with fungal pathogen-associated molecular patterns (PAMPs) and other more complex mechanisms (i.e., secreted aspartyl proteases (Sap)-mediated NLRP3 activation and the cytolytic peptide toxin candidalysin) $[17,18]$. The activation of the innate immune system by a series of proinflammatory cytokines and chemokines leads to the recruitment of neutrophils to the vaginal mucosa, subsequently exacerbating symptomatic disease [17-19]. 
Moreover, Candida species also can exert tissue damage by direct invasion of its hyphal filaments or secretion of virulence effectors [19].

Candida species have a dual lifestyle as both a vaginal commensal and an opportunistic pathogen [20]. The switch between yeast and hyphal growth is critical for virulence, affecting numerous properties including phenotypic and biochemical properties [18,21]. Virulence traits are created by microorganisms and may subsequently lead to tissue damage, making them more pathogenic [22]. Virulence traits include the ability to make a morphological switch from yeast to hyphae, modulating the expression of adhesins to help the Candida adhere to epithelial cells, the expression of invasins, the formation of biofilms, the secretion of hydrolytic enzymes such as Sap and candidalysin, and the ability to escape from phagocytosis by neutrophils and macrophages [17,18,23-25].

The pathogenesis of VVC is a gradual process that goes through several stages, from adherence to the vaginal epithelium, recognition (caused by a burden threshold of hyphae), becoming invasive, the possibility of biofilm formation, and dispersion of planktonic cells that reinitiates the complete process (see Figure 1).

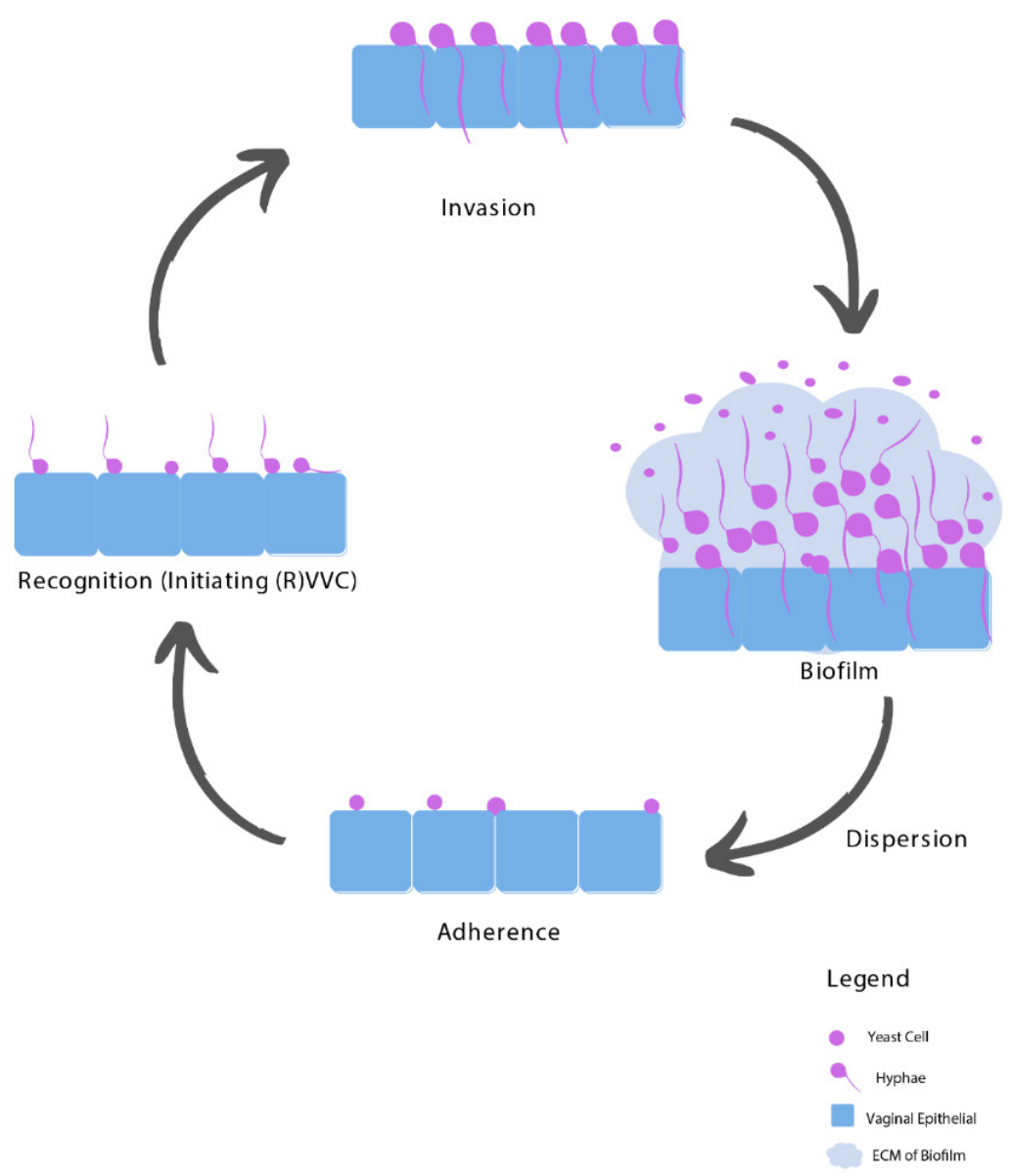

Figure 1. Biofilm formation of Candida species during the pathogenesis of (R)VVC. Yeast cells adhere to the vaginal epithelium and subsequently form hyphae, which together with secretion of Candidalysin determine recognition by the immune system and drive damage and vulvovaginal immunopathogenesis. Invasion of the Candida follows through hyphal extension, relying on both the strain and host factors. Next, biofilms can start to form, from which Candida cells can be released (dispersion) as planktonic cells and reinitiate the complete process.

\subsection{Adhesion}

The most important phase of the initial contact between potential pathogen and host is the adherence of yeast cells to epithelial cells. Consequently, an interaction follows between epithelial receptors and Candida adhesins. These Candida adhesins vary depending on the 
morphological status of the Candida, i.e., yeast or hyphae [26]. After this initial contact, hyphae will grow out of the yeast cells, which is the first step in the pathogenesis [27]. The progress of the infection is determined by the hyphal-expressed adhesins that play a key role in the pathogenesis [26]. In most cases, yeast cells adhere directly to the epithelial cells; however, there may also be direct adhesion of the hyphal form of Candida to epithelial cells, as hyphae grow from one epithelial cell to an adjacent epithelial cell [26]. After adherence to the vaginal epithelium, the Candida cells may form hyphae and become recognized by the immune system [26].

\subsection{Recognition}

The fact that Candida species have a dual lifestyle as both a vaginal commensal and opportunistic pathogen requires epithelial cells to have a mechanism to discriminate between the colonizing yeast and the invasive hyphal form [20]. Candida species can be recognized via two different pathways. The first phase is represented by an early transient response that occurs in a morphologically independent manner. The second phase starts when a burden threshold of hyphae is reached; this is a stronger response to hyphae, which in turn leads to activation of epithelial cells and the production of cytokines, chemokines, and other inflammatory mediators [26]. The hyphal burden plays a significant role in affecting epithelial activation because the presence of hyphae goes undetected below a certain threshold level. This is supported by in vivo experiments in a murine model of vaginitis, where the hyphal form was needed to cause damage to the epithelium, releasing pro-inflammatory cytokines and neutrophil recruitment [26]. Moreover, healthy women who were challenged intravaginally with Candida showed a differential susceptibility to develop symptomatic VVC when having no history of VVC $(15 \%)$ compared to women with a history of infrequent VVC (55\%) [28].

\subsection{Invasion}

Invasion of Candida species can occur with the help of invasins after a switch from the yeast to the hyphal form $[27,29]$. Invasion into host cells can be achieved by endocytosis or active penetration [29]. This consequently leads to damage to the epithelial cells via necrosis and apoptosis, hence loss of epithelium. An in vivo study demonstrated a significantly lower cell damage caused by non-hyphal mutants compared to hyphal mutants [26,30].

\subsection{Biofilms}

Biofilm formation may be the main etiological factor contributing to antifungal resistance and is a likely contributor to treatment failure in RVVC [27,31-33]. It is suggested that the ability to form biofilms is a major virulence trait of Candida species in the pathogenesis of VVC [32,34]. After the invasion stage, an extracellular matrix (ECM) may be developed, which results in a 'biofilm' that encapsulates the Candida cells. This ECM consists of exopolymeric macromolecules, including polysaccharides, proteins, lipids, and nucleic acids, which are secreted by sessile cells within the biofilm. A mature biofilm is characterized by a structured mixture of yeast-form and hyphal cells surrounded by ECM, and it provides protection for the yeast against environmental challenges. In the final stage, the biofilm slowly disperses yeast-form cells into the surrounding, which may be able to colonize other surfaces $[20,31]$.

Several studies confirm the role of biofilms in the pathogenesis of VVC. An in vitro study showed the ability of five types of Candida species isolated from patients with VVC, including Candida albicans and Candida glabrata, to form biofilms [35]. A study performed on clinical isolates from 300 women with at least two episodes of VVC demonstrated the ability to form heterogeneous biofilms [36]. In vivo and ex vivo murine vaginitis models confirmed the presumption of Candida albicans biofilm formation on vaginal epithelial cells, possibly due to the high fungal burden $[33,36]$. Candida albicans biofilms were also formed on reconstituted human vaginal epithelial cells [33,37]. Although the role of biofilms in clinical VVC remains disputed, many researchers consider them as important drivers of 
disease $[32,33,36,38]$. More research is needed to elucidate the role of Candida biofilms in the pathogenesis of (R)VVC [33].

\section{Risk Factors of RVVC}

VVC is considered a multifactorial disease, where the Candida strain and its virulence factors, an imbalanced vaginal microbiota composition, host-related predisposing factors, and idiopathic factors determine the disease onset and relapsing property [4].

\subsection{Imbalanced Vaginal Microbiota Composition}

Alteration in the mucosal ecosystem leading to fungal dysbiosis can lead to (R)VVC and its symptoms [4]. A healthy vaginal microflora consists of different microorganisms, mainly Lactobacilli, but also accommodating fungi such as Candida albicans and Candida glabrata, living in symbiosis. Lactobacilli species play an important role in maintaining a healthy vaginal microbiome [4]. Through their presence, Lactobacilli species decrease opportunism of potentially pathogenic microorganisms by microbial competition, which reduces the adherence of Candida species to the vaginal epithelium [24,39]. Lactobacilli exert several other beneficial properties, such as decreasing the vaginal $\mathrm{pH}$, which in healthy women of reproductive age remains between 4 and 4.5. As the fermentation of glycogen within the vaginal epithelium produces lactic acid, the vaginal $\mathrm{pH}$ decreases and non-resident microbiota are suppressed, thereby protecting against opportunistic infections [27,39-41]. In addition, Lactobacilli produce bacteriocins and hydrogen peroxide $\left(\mathrm{H}_{2} \mathrm{O}_{2}\right)$, which positively affect the commensal community by limiting pathogens through their antimicrobial function [39]. Moreover, Lactobacilli species induce the expression of genes that prevent the adherence of yeast to the epithelium and limit yeast-to-hyphal formation, keeping the Candida in its less invasive form and consequently inhibiting overgrowth of the Candida [24]. Lastly, Lactobacilli cause modulation of the local immune system [39].

When the healthy microbial balance is disturbed, Lactobacilli may lose their ascendancy, and other microorganisms, such as Candida albicans, can foster and cause overgrowth. Multiple factors can alter the vaginal microbiota and disturb the balance between tolerance and invasion of Candida species. Important drivers for the pathogenesis of VVC are changes in the Lactobacilli community, elevated estrogen levels (i.e., due to oral contraceptives, hormone replacement therapy (HRT) used in post-menopause, being in the luteal phase of the menstruation cycle or pregnancy), an elevated $\mathrm{pH}$, and the presence of glucose and eicosanoids (such as prostaglandin E2 and thromboxane B2). Other determinants have an inhibitory effect on VVC such as lactate and the presence of short-chain fatty acids such as acetate, butyrate, and propionate B $[4,6]$.

\subsection{Host-Related Predisposing Factors}

A broad spectrum of host-related predisposing factors such as genetic background, (uncontrolled) diabetes mellitus, altered immune status, use of steroids, and antibiotics therapy, as well as behavioral factors such as sexual activity, hormone replacement therapy, and use of contraceptives including intrauterine devices, have been associated to promote VVC pathology $[1,2,4]$.

\subsection{Idiopathic $R V V C$}

There are no predisposing factors in $20-30 \%$ of the RVVC patients. It is suggested that the Candida strain, its virulence, and inter-individual differences play a key role in idiopathic RVVC pathogenesis [1,4]. Several epidemiologic and cohort studies demonstrated that genetic mutations and polymorphisms and ethnicity play a role [4,31]. Moreover, NAC species are also associated with recurrent infections in VVC patients, likely because of their natural resistance towards azole-based antifungal agents [4]. 


\section{Treatment of RVVC and Its Efficacy}

The standard treatment for RVVC consists of 10-14 days of induction therapy with a topical antifungal agent or oral fluconazole $150 \mathrm{mg}$, followed by fluconazole $150 \mathrm{mg}$ a week for 6 months [5,42]. Fluconazole is primarily fungistatic by selectively inhibiting the fungal cytochrome P450-dependent enzyme named lanosterol 14- $\alpha$-demethylase, encoded by the ERG11 gene, which converts lanosterol to ergosterol [43,44]. Ergosterol is an essential component of fungal plasma membranes, and inhibition of its biosynthesis leads to loss of membrane structural and functional properties, including altered fluidity and permeability $[44,45]$. Moreover, toxic methylated sterols accumulate in the fungal cell membrane via ERG3, and cell growth is arrested [43,46,47].

The morbidity of RVVC is dramatically increasing, and also the costs associated with medical care rise accordingly [4]. It is difficult to achieve a long-term cure. In research published in the New England Journal of Medicine, the proportions of women who remained disease-free at 6, 9, and 12 months after weekly treatment with fluconazole $150 \mathrm{mg}$ for 6 months were $90.8 \%, 73.2 \%$, and $42.9 \%$, respectively [3]. Despite fluconazole being effective to relieve VVC symptoms, a long-term cure is hard to achieve and maintain [2,3].

\subsection{Resistance towards Fluconazole}

Since fluconazole is fungistatic rather than fungicidal, there is an increased opportunity to develop acquired resistance in the presence of this antifungal [46]. There are several challenges in fluconazole treatment such as an increase in antifungal resistance and VVC caused by NAC species, as well as the existence of biofilms [48]. Epidemiologic studies confirm that mostly all women diagnosed with fluconazole-resistant Candida albicans were previously exposed to fluconazole [48]. A study determined the prevalence of vaginal colonization by Candida in women and evaluated the susceptibility for the antifungal treatment with fluconazole [6]. There were 612 women recruited to determine the presence of Candida species, of which $20.1 \%$ were colonized with yeasts. In most cases, Candida albicans $(68.3 \%)$ was found, followed by Candida glabrata $(16.3 \%)$ and Candida parapsilosis $(8.9 \%)$. A total of $79 \%$ of the Candida isolates were susceptible to fluconazole [6]. As expected, the susceptibility of this mixed population of Candida species is slightly lower than that of Candida albicans alone. The susceptibility rates of Candida albicans to fluconazole reported in other studies are $89.5 \%, 87.5 \%, 86.5 \%, 85.3 \%$, and $95.3 \%$, meaning about only $5-15 \%$ of Candida albicans strains are resistant [49-53]. To illustrate, resistance levels of Candida krusei (66.6\%), Candida glabrata (60\%), Candida kefyr (45.5\%), and Candida parapsilosis (6.9\%) are typically much higher [49]. Limited options remain for maintenance therapy for RVVC when azole resistance appears [1].

\subsection{Unnecessary and Inappropriate Use of Fluconazole}

Fluconazole is a commonly used antifungal agent and is easily accessible, which increases the risk of developing resistance. For example, the over-the-counter availability of antifungal agents combined with the frequent empiric prescription of fluconazole for sporadic VVC and the frequent use of a low weekly dose of fluconazole as a maintenance regimen facilitates fluconazole-resistance by Candida species, subsequently leading to RVVC [48]. Long-term maintenance therapy should be based on diagnostic confirmation to avoid unnecessary and inappropriate use [48].

\subsection{Non-Albicans Species}

VVC caused by NAC species is increasingly common due to overuse and misuse of antifungal agents $[6,15,54]$. Furthermore, a major concern regarding the increased incidence of VVC caused by NAC species is that such infections are often more difficult to treat because they are less susceptible to azoles and are more frequently resistant $[6,15,24]$. 


\subsection{Biofilms Complicate RVVC Treatment}

The biofilm formation in the pathogenesis of VVC provides elevated virulence and resistance towards antifungal therapy such as fluconazole [27,32,33]. A 1000-fold higher resistance profile of biofilms compared to their planktonic counterparts has been described $[20,55,56]$. Biofilms are also less sensitive to eradicate by the host immune system. A study of clinical isolates obtained from women with at least two episodes of VVC confirmed a lower antifungal susceptibility for biofilms in comparison with the planktonic antifungal susceptibility [32].

Currently, no treatment targets Candida biofilm formation and eradication, making biofilms a significant clinical challenge that urgently requires novel treatment options $[31,33,34,48]$.

\section{Medical-Grade Honey as an Alternative Treatment Option}

The high recurrence rate of complaints after fluconazole treatment may be attributed to the fact that fluconazole only interacts with the yeast, hyphae, and invasive Candida stages (Figure 2). In contrast, when an established biofilm is present, the ECM prevents the fluconazole from reaching the Candida cells, and therefore it will not have an effect on biofilms [57]. Moreover, fluconazole does not affect the vaginal mucosal response [1,3,4]. Since ancient times, honey has been used for wound treatment and care because of its antimicrobial and wound healing activities. Acquired azole resistance, the epidemiological shift from Candida albicans to NAC species, and the existence of biofilms demand better treatment options. Medical-grade honey (MGH) could be an accessible, effective, and affordable option [24]. To assure the safety and efficacy of honey for clinical application, strict guidelines are followed to establish MGH [58]. MGH is effective in acute and chronic wounds and provides rapid epithelization and wound contraction, has anti-inflammatory activity, stimulates debridement, decreases pain, resolves infections, decreases wound healing time, and is cost-effective [59]. The use of honey for reducing biofilm formation on indwelling plastic devices such as urinary catheters are also considered, but more research is needed [60,61].

As mentioned before, four key factors determine the progression and development of RVVC: the presence of Candida, the population of Lactobacilli, the microenvironment, and host-related factors. In contrast to fluconazole, MGH may affect all these factors via multiple mechanisms (Figure 2, Table 1).

Table 1. Overview antipathogenic activity of fluconazole and MGH.

\begin{tabular}{ccc}
\hline Characteristic & Fluconazole & MGH \\
\hline Candida albicans & + & + \\
\hline (Increased raise in VVC caused by) NAC species & - & + \\
\hline Biofilms & - & + \\
\hline Increased resistance & - & + \\
\hline Microenvironment/vaginal mucosal response & - & +- \\
\hline Lactobacilli & - & + \\
\hline pH & - & + \\
\hline Osmotic effect & - & + \\
\hline Antimicrobial & + & + \\
\hline Anti-inflammatory & - & \\
\hline Antioxidative & - & \\
\hline$-:$ no effect; +: positive effect; +-: possible effect. & & + \\
\hline
\end{tabular}




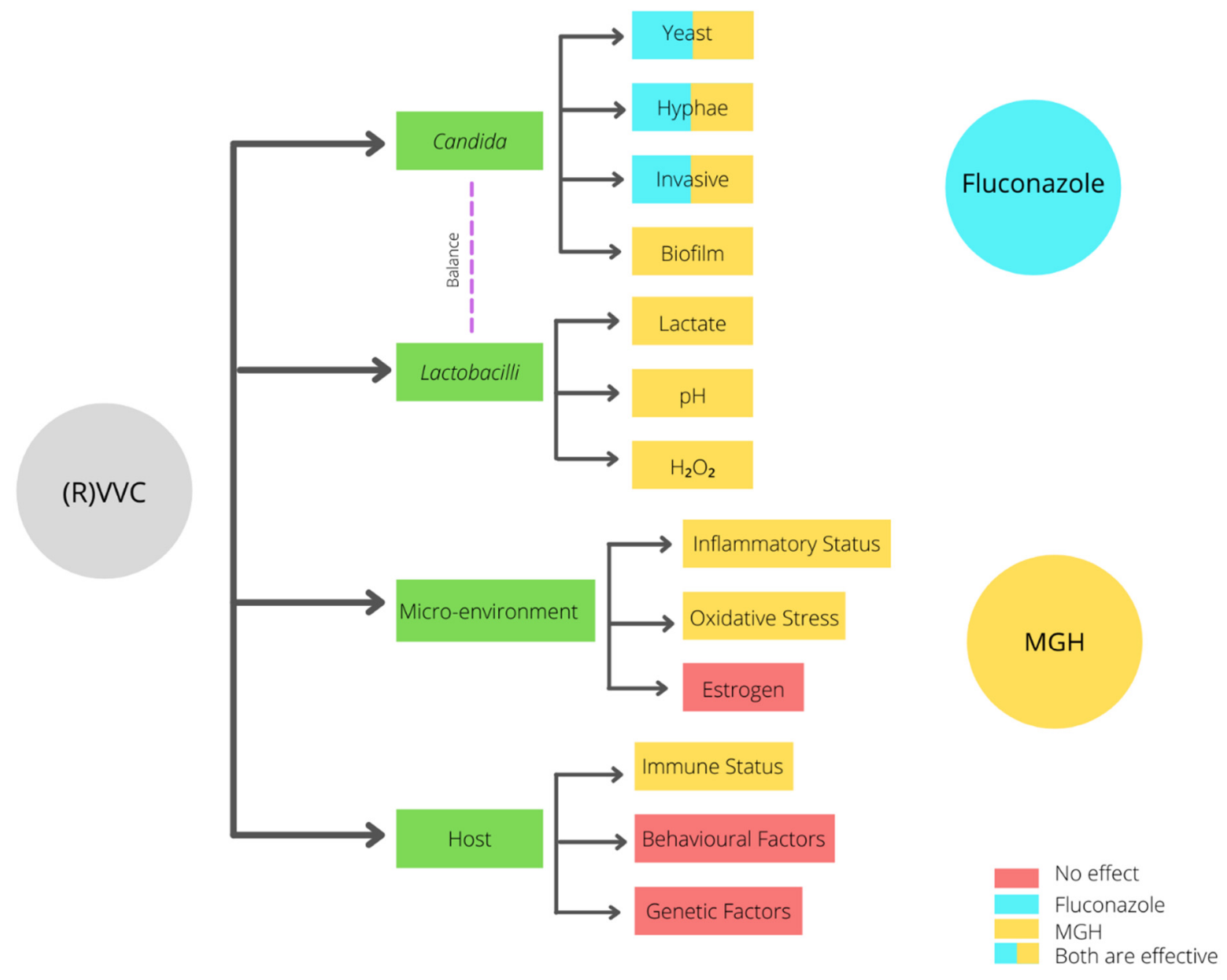

Figure 2. Differential antipathogenic activity of fluconazole and MGH on the pathogenesis of RVVC.

\subsection{The Antimicrobial Activity of MGH against Candida Species}

MGH has multiple physicochemical properties that result in antimicrobial and healing activities. MGH consists of more than 200 different constituents, of which the relative majority consists of carbohydrates (about $80 \%$ ), such as glucose and fructose, and water $(17-18 \%)$, as well as a small number of other substances such as minerals, vitamins, organic acids, enzymes, phenolic compounds, flavonoids, and other phytochemicals $[58,62]$.

There are a couple of factors responsible for the antifungal effects of honey. The sugarrich composition has an osmotic activity, attracting fluid from the surrounding environment, and will also lead to dehydration of present microorganisms, which makes the microorganisms vulnerable [63]. One of the strongest antifungal factors of MGH is hydrogen peroxide [62-64]. When the sugars from the honey come into contact with water, under the presence of the enzyme glucose oxidase in $\mathrm{MGH}$, hydrogen peroxide will be formed and released: $\mathrm{C}_{6} \mathrm{H}_{12} \mathrm{O}_{6}$ (glucose) $+\mathrm{H}_{2} \mathrm{O}+\mathrm{O}_{2}+$ glucose oxidase $\rightarrow \mathrm{C}_{6} \mathrm{H}_{12} \mathrm{O}_{7}$ (gluconic acid) $+\mathrm{H}_{2} \mathrm{O}_{2}$ (hydrogen peroxide) $[63,65,66]$. Hydrogen peroxide is a well-known antimicrobial molecule that will kill almost all microorganisms, including those resistant to antibiotics $[62,63,66,67]$. The acidic $\mathrm{pH}$ of MGH makes it even harder for most microorganisms to persist. Moreover, other molecules that are present in MGH also have a direct antimicrobial effect, such as phenolic compounds, flavonoids, methylglyoxal, and bee defensin-1 [62]. Since the antimicrobial activity of MGH is based on multiple mechanisms, microorganisms are not capable of developing resistance towards MGH [62,66,68-71].

MGH can play a beneficial role in all Candida stages, whereas fluconazole (when the Candida is not resistant) only interacts with the first three stages from yeast to invasion (except the formation of biofilms) by interfering with the plasma membrane synthesis, 
adhesion, and growth of the Candida [43,46,72]. The biofilm forms a physical shield for fluconazole, preventing the reaching of the Candida cells [73,74]. The activity of MGH against biofilms may therefore be a discriminating factor that results in a long-term cure. The antifungal activity of honey against Candida species has been widely investigated in vitro (Table 2). In these studies, species of patients with VVC were isolated, and minimal inhibitory concentrations (MIC) and minimal fungicidal concentrations (MFC) were determined, also against fluconazole-resistant species and biofilm models.

Table 2. Overview in vitro studies investigating the antimicrobial activity of MGH against Candida species.

\begin{tabular}{cl}
\hline Selected Studies & \multicolumn{1}{c}{ Methods } \\
\hline & $\begin{array}{l}\text { Clinical isolates of Candida albicans, Candida glabrata, and } \\
\text { Candida dubliensis were tested against four different } \\
\text { honeys: }\end{array}$ \\
Irish et al. 2006 & -Jarrrah honey with hydrogen peroxide activity \\
[75] & -Medihoney \\
& -Comvita wound care 18+, a pure Leptospermum honey \\
& -Artificial honey used to simulate the high sugar levels \\
& found in honey \\
\hline
\end{tabular}

Fungicidal efficacy of 3 Iranian honey samples against

Shokri et al. 2017 fluconazole-resistant Candida species (including Candida [76] albicans, Candida glabrata, Candida krusei, and Candida tropicalis) isolated from HIV+ patients with candidiasis

Ansari et al. 2013 Effect of jujube honey on Candida albicans growth and [77] biofilm formation

Banaean-

Boroujeni et al.

2013 [7]

Effect of Iranian honey and miconazol against Candida albicans, in vitro

\begin{tabular}{cl}
\hline $\begin{array}{c}\text { Estevinho et al. } \\
\text { 2011 [78] }\end{array}$ & $\begin{array}{l}\text { Monofloral lavender honey samples were analyzed to } \\
\text { test antifungal effect against Candida albicans, Candida } \\
\text { krusei, and Cryptococcus neoformans }\end{array}$ \\
\hline $\begin{array}{c}\text { Koc et al. 2009 } \\
\text { [67] }\end{array}$ & $\begin{array}{l}\text { Antifungal activity of four Turkish honey samples } \\
\text { against 40 yeast species (Candida albicans, Candida Krusei, } \\
\text { Candida Glabrata, and Trichosporon spp.) }\end{array}$ \\
\hline
\end{tabular}

Hermanns et al. Five clinical Candida albicans isolates and a control strain 2019 [79] were tested against unprocessed Mexican Yucatan honey with hydrogen peroxide activity and L-Mesitran soft

\begin{tabular}{cl}
\hline $\begin{array}{c}\text { Al-Waili et al. } \\
2005 \text { [80] }\end{array}$ & $\begin{array}{l}\text { Effects of honey, olive oil, and beeswax and the mixture } \\
\text { on growth of Staphylococcus aureus and Candida } \\
\text { albicans isolates }\end{array}$ \\
\hline Khosravi et al. & $\begin{array}{l}\text { Anti-candidal activity of 28 locally produced honeys } \\
\text { from Iran against Candida albicans, Candida parapsilosis, } \\
\text { Candida tropicalis, Candida kefyr, Candida glabrata, and } \\
\text { Candida dubliniensis }\end{array}$ \\
\hline $\begin{array}{c}\text { Fernandes et al. } \\
2021[62]\end{array}$ & $\begin{array}{l}\text { Antifungal activity of five Portuguese honeys and } \\
\text { Candida albicans, Candida tropicalis, Candida glabrata, and } \\
\text { Candida parapsilosis }\end{array}$ \\
\hline
\end{tabular}

\section{Results}

-Jarrah honey has a MIC of $18.5 \%$ compared to $38.2 \%$ for Medihoney, 39.9\% for Comvita honey, and $42.6 \%$ for artificial honey against Candida albicans. Jarrah honey was also significantly more active against Candida Glabrata and Candida dubliensis.

-Honey was effective against isolates who are resistant to itraconazole and/or fluconazole.

All tested honeys had antifungal activity against

FLU-resistant Candida species, ranging from $20 \%$ to $56.25 \%(v / v)$ and $25 \%$ to $56.25 \%(v / v)$ for MICs and minimum fungicidal concentrations (MFCs), respectively.

No statistically significant differences were observed between the honey samples.

$40 \% w / v$ Jujube honey interferes with formation of Candida albicans biofilms and disrupts established biofilms.

Honey prevented growth of Candida albicans greatly only at an $80 \%$ concentration, whereas miconazol inhibited it completely. Honey did not interfere with the Lactobacillus.

The honey concentration that inhibited $10 \%$ of the yeasts' growth ranged from $31 \%$ (Candida albicans) and $16.8 \%$ (Candida krusei).

The honeys had antifungal activity for Candida albicans at a mean MIC of $45.56 \%$, for Candida Glabrata at $64.09 \%$, and for Candida krusei at $56.88 \%$.

-No effect of 40\% Mexican Yucatan MGH alone. -L-mesitran has fungistatic (25-50\% MIC) and fungicidal (50\% MFC) activity, corresponding to honey concentrations of $10 \%$ and $20 \%$, respectively. -The supplements in L-Mesitran enhanced the antimicrobial activity of the honey formulation.

The amount of honey present in the honey mixture $(50 \% w / v)$ completely inhibited the growth of Candida albicans.

The MIC and MFC means of different honeys were $24-47 \%$ and $29-56 \%$ against different Candida species, respectively.

-All honeys had a potent activity against Candida species (MIC 25-50\% (w/v)).

-Biofilms can be reduced at a concentration of $50-75 \%$ honey. 


\subsection{MGH Resolves Non-Albicans Candida Species}

As noticed previously, NAC species create a major problem in the treatment of RVVC. The incidence of NAC species increases, and they demonstrate elevated resistance for antifungal agents [82]. Besides the efficacy of honey against Candida albicans, several studies have demonstrated the susceptibility of NAC species such as Candida tropicalis, Candida glabrata, Candida parapsilosis, Candida kefyr, and Candida dubliniensis to honey, which could fulfill the growing demand for new antifungal agents [62,75,81]. MGH does not distinguish between the different Candida species, their virulence factors, and their resistance profiles.

\subsection{The Effect of MGH on Biofilms}

The ECM of the biofilm is responsible for increased resistance, preventing antifungal agents from penetrating the biofilm and shielding the Candida cells from the host immune response. MGH can be the solution for this problem against the failed treatment of Candida biofilms in RVVC. MGH reduces the production of extracellular polysaccharide matrix, which leads to the prevention of biofilm formation and also promotes the eradication of mature biofilms [62,77].

\subsection{Lactobacilli Are Not Affected by MGH}

Lactobacilli maintain a healthy vaginal microbiome and are natural competitors of Candida in the vagina. When the concentration of Lactobacilli decreases, an overgrowth of Candida species can occur. It is important that MGH does not interrupt the beneficial effects of Lactobacilli, which is supported by an in vitro study confirming no interference [7,24]. Moreover, an in vivo study in rats showed that honey enhanced the growth of Lactobacilli [83]. Furthermore, MGH has some overlapping characteristics with Lactobacilli such as the production of hydrogen peroxide and maintaining a low $\mathrm{pH}$, being able to replace or augment these effectors.

\subsection{MGH Modulates the Vaginal Microenvironment}

Besides the antimicrobial activity demonstrated above, MGH has anti-inflammatory and antioxidative properties that can further benefit the vaginal environment, especially under infected and inflammatory conditions $[84,85]$. A pro-inflammatory state of the vagina makes the tissue more prone to Candida infections, as is the case with RVVC [19]. Phytochemicals, such as flavonoids, polyphenolic compounds, and vitamin C, are antioxidants present in the $\mathrm{MGH}$, which subsequently scavenge free oxygen radicals, reducing inflammation and minimizing tissue damage $[62,86,87]$. Therefore, we are confident that MGH not only will fight the infection but also will harness the tissue for new infections by attenuating the inflammatory state and skew it towards protection.

\subsection{Effect of MGH on the Immune Status}

The pro-inflammatory and antioxidative activity of MGH may, in addition to changing the microenvironment, also affect the immune response. Leukocytes migrate in response towards cytokines and chemokines that are produced under the influence of the local microenvironment $[88,89]$. By influencing the microenvironment $\left(\mathrm{pH}, \mathrm{H}_{2} \mathrm{O}_{2}\right.$, inflammatory and oxidative state), MGH can modulate immunological mediators and affect the immune response [90]. For example, MGH may stimulate the recruitment of neutrophils and monocytes to the site of injury and may switch the phenotype of macrophages from proinflammatory towards anti-inflammatory, creating a 'protective' microenvironment [91,92]. Moreover, the immunomodulatory properties of MGH may prevent infections by stimulating the immune response in combination with their antimicrobial activity. Interestingly, a prophylactic activity of an MGH-based wound care formulation has previously been found in randomized controlled trials, investigating a single subcutaneous application in both equine lacerations and colic surgeries $[93,94]$. In these studies, the infection rate decreased three- and fourfold, respectively. 


\subsection{Clinical Studies Supporting a Role for MGH in the Treatment of $(R) V V C$}

MGH has shown beneficial effects in the treatment of (R)VVC. Several studies confirmed a potent role for honey in the treatment of (R)VVC. Most studies demonstrated a significant decrease in inflammation, itching, and discharge. A summary of these studies is presented in Table 3.

Table 3. Overview clinical studies investigating the effect of honey on VVC. RCT: randomized controlled trial.

\begin{tabular}{|c|c|c|c|c|}
\hline $\begin{array}{l}\text { Selected } \\
\text { Studies }\end{array}$ & Treatment & $\begin{array}{c}\text { Trial } \\
\text { Design }\end{array}$ & $\begin{array}{l}\text { Purpose/ } \\
\text { Objective/ } \\
\text { Content }\end{array}$ & Results/Conclusion \\
\hline $\begin{array}{c}\text { Banaeian } \\
\text { et al. } 2017 \\
\text { [95] }\end{array}$ & $\begin{array}{l}\text { Clotrimazole } 1 \% \text { cream } \\
(n=36) \text { versus honey } \\
\text { cream (honey and } \\
\text { neutral crème in } 70: 30 \\
\text { ratio) }(n=44) \text {, both } 5 \mathrm{~g} \\
\text { with applicator for } 7 \\
\text { nights }\end{array}$ & $\mathrm{RCT}$ & $\begin{array}{l}\text {-Inflammation } \\
\text {-Vaginal discharge } \\
\text {-Irritation/itching } \\
\text { At baseline in the } \\
\text { fourth and eight } \\
\text { days of treatment } \\
\text {-Recurrence after } \\
3 \text { months }\end{array}$ & $\begin{array}{l}\text {-Significant decrease in discharge, inflammation } \\
\text { and itching in both groups. } \\
\text {-Inflammation and discharge scores were } \\
\text { significantly lower on the eight day in the } \\
\text { clotrimazole group, compared to the honey group. } \\
\text {-No significant difference in the itching score on the } \\
\text { eighth day between the honey and clotrimazole } \\
\text { groups. } \\
\text {-Greater efficacy of honey for RVVC. After } \\
3 \text { months, } 5 \text { of } 17 \text { patients from the honey group } \\
\text { had a recurrent infection, and } 8 \text { of } 15 \text { patients of the } \\
\text { clotrimazole group had a recurrent infection. } \\
\text {-Honey decreased VVC symptoms without } \\
\text { affecting lactobacillus. }\end{array}$ \\
\hline $\begin{array}{c}\text { Seifinadergoli } \\
\text { et al. } 2018 \\
{[96]}\end{array}$ & $\begin{array}{l}\text { Clotrimazole } 1 \% \text { cream } \\
(n=53) \text { versus } 50 \% \\
\text { honey gel }(n=53), \text { both } \\
5 \text { g with applicator for } \\
8 \text { nights }\end{array}$ & $\mathrm{RCT}$ & $\begin{array}{l}\text {-Vaginal discharge } \\
\text {-Itching } \\
\text {-Burning } \\
\text {-Dyspareunia } \\
\text {-Urinary problem } \\
\text { At baseline, in the } \\
\text { fourth and eight } \\
\text { days after treatment }\end{array}$ & $\begin{array}{l}\text {-Vaginal discharge for } 68 \% \text { in honey group versus } \\
72 \% \text { in clotrimazole group after } 8 \text { days }(p<0.001) \text {. } \\
\text {-Itching for } 4 \% \text { in honey group versus } 10 \% \text { in } \\
\text { clotrimazole group after } 8 \text { days }(p<0.001) \text {. } \\
\text {-Burning for } 4 \% \text { in honey group versus } 0 \% \text { in } \\
\text { clotrimazole group after } 8 \text { days ( } p<0.001) \text {. } \\
\text {-Culture was } 50 \% \text { positive in honey group versus } \\
20 \% \text { in clotrimazole group after eight days, and } \\
\text { there was no statistical difference. } \\
\text {-Equally effective in making the culture and wet } \\
\text { smear results negative. } \\
\text {-Honey can be used as an alternative for other } \\
\text { antifungal drugs. }\end{array}$ \\
\hline $\begin{array}{c}\text { Darvishi } \\
\text { et al. } 2015 \\
\text { [97] }\end{array}$ & $\begin{array}{l}\text { Clotrimazole } 1 \% \text { cream } \\
(n=35) \text { versus cream } \\
\text { mixed of yogurt and } \\
\text { honey }(n=35), \text { both } 5 \mathrm{~g} \\
\text { with applicator for } 7 \\
\text { days }\end{array}$ & $\mathrm{RCT}$ & $\begin{array}{l}\text {-Itching } \\
\text {-Irritation } \\
\text {-Dysuria } \\
\text {-Dyspareunia } \\
\text {-Discharge } \\
\text {-Cultures } \\
\text { At baseline, } 7 \text { days } \\
\text { after treatment, } \\
14 \text { days after } \\
\text { treatment }\end{array}$ & $\begin{array}{l}\text {-Itching for } 2.9 \% \text { in yogurt and honey group versus } \\
25.7 \% \text { in clotrimazole group } 14 \text { days after treatment } \\
(p<0.02) \text {. } \\
\text {-Irritation for } 2.9 \% \text { in yogurt and honey group } \\
\text { versus } 22.9 \% \text { in clotrimazole group } 14 \text { days after } \\
\text { treatment }(p<0.04) \text {. } \\
\text {-Discharge for } 2.9 \% \text { in yogurt and honey group } \\
\text { versus } 22.9 \% \text { in clotrimazole group } 14 \text { days after } \\
\text { treatment ( } p<0.04) \text {. } \\
\text {-Significant improvement in symptoms in yogurt } \\
\text { and honey group compared to clotrimazole } \\
(p<0.05) \text {. } \\
\text {-No significant differences in mycological cure rate } \\
\text { between yoghurt and honey ( } 71.4 \%) \text { and } \\
\text { clotrimazole }(85.7 \%) \text { groups at } 14 \text { days after } \\
\text { treatment. }\end{array}$ \\
\hline
\end{tabular}


Table 3. Cont.

\begin{tabular}{|c|c|c|c|}
\hline $\begin{array}{c}\text { Selected } \\
\text { Studies }\end{array}$ & Treatment & $\begin{array}{c}\text { Trial } \\
\text { Design }\end{array}$ & $\begin{array}{c}\text { Purpose/ } \\
\text { Objective/ } \\
\text { Content }\end{array}$ \\
\hline
\end{tabular}

Tioconazole $100 \mathrm{mg}$

vaginal tablet $(n=47)$ once daily for 7 days versus bee Abdelmonem honey and yogurt et al. 2012 mixture vaginally with [98] an applicator $30 \mathrm{~g}$ $62.5 \%$ honey twice a day for 7 days $(n=82)$ by pregnant women
Prospective -Clinical cure compara- -Mycological cure tive Before treatment study and after treatment

-Clinical cure rate was significantly higher in the honey and yogurt group (87.8\%) compared to the tioconazole group $(72.3 \%)$.

-The mycological cure rate was significantly higher in the tiozonazole group (91.5\%) compared to the honey and yogurt group (76.9\%).

-Itching was 3.7\% in the honey and yogurt group versus $14.9 \%$ in the tioconazole group.

-Discharge was $4.9 \%$ in the honey and yogurt group versus $12.8 \%$ in the tioconazole group.

-Vulvo-vaginal redness was 3.7\% in the honey and yogurt group versus $8.5 \%$ in the tioconazole group.

-Clinical cure rate from sider honey $(86.6 \%)$ compared to fluconazole (40\%).

-Mycological cure rate from sider honey $(76.7 \%)$

Fluconazole $(n=30)$

Aboushady versus Sider honey

et al. $2015 \quad 5 \mathrm{~mL}(80 \%)(n=30)$

[99] applied vaginally twice/day for 7 days
Quasi- -Clinical cure experimental -Mycological cure design Before treatment and after treatment

compared to fluconazole $(43.3 \%)$.

-Vaginal discharge after sider honey (10\%) compared to fluconazole (50\%).

-Burning sensation after sider honey $(0 \%)$ compared to fluconazole (33.3\%).

-Itching after sider honey ( $0 \%$ ) compared to fluconazole $(10 \%)$.

-Itching after 14 days of treatment with

-Mixture of honey and yogurt cream $(n=35)$ -Honey cream $(n=35)$ -Clotrimazole cream $(n=35)$ versus mixture Jahdi et al. of honey and yogurt 2021 [100] cream $(n=35)$ versus honey cream $(n=35)$; each group was treated for 7 nights, all $5 \mathrm{~g}$ with applicator intravaginally
-Leucorrhea

-Itch

-Irritation

-Dysuria

-Dyspareunia

RCT Before, at 7 and 14 days after treatment -Mycological cure rate 7 and 14 days after treatment clotrimazole $(25.7 \%)$ versus yogurt and honey $(2.9 \%)$ versus honey $(14 \%)$.

-Irritation after 14 days of treatment with clotrimazole $(22.9 \%)$ versus yogurt and honey $(2.9 \%)$ versus honey $(5.7 \%)$.

-Significant difference between yogurt and honey group and honey vaginal cream group versus clotrimazole group in improving symptoms. -Negative culture 14 days after treatment was found in yogurt and honey group (71.4\%), honey group $(68.6 \%)$, and clotrimazole group $(85.7 \%)$ with no significant differences $(p>0.05)$.

-In both groups, symptoms improved after treatment $(p<0.001)$.

-In the honey cinnamon vaginal cream group, burning was significantly less than the clotrimazole group ( $p=0.008)$.

-Culture results were similar after treatment $(p=0.461)$.

-Honey cinnamon vaginal cream can be advisable to use it as an alternative to the clotrimazole vaginal cream.

-Alleviations occurred in symptoms and signs of vaginitis after treatment with honey and clotrimazole.

-The success rate was 100\% in the honey group and in the honey and clotrimazole group.

-Use of honey alone represents a novel and effective formulation for the treatment of vaginitis. 


\subsection{Considerations for MGH Application}

In contrast to fluconazole, MGH exerts pleiotropic effects and acts via multiple pathways, as mentioned above. This may be beneficial for the treatment of RVVC as it can act on multiple relevant targets. For example, the multitude of antimicrobial mechanisms ensures effective killing of the different Candida species, irrespective of their resistance profile. These different mechanisms lead to dehydration of the fungal cells, weakening of the cell membranes, and causing of intracellular damage, resulting in limiting its reproduction and causing cell death, while simultaneously preventing the risk of resistance. Please note that some of the proposed targets demand further investigation. For example, more research on the effect of MGH on the Lactobacilli population and the influence on the $\mathrm{pH}$ and lactate and hydrogen peroxide production in a complete ecosystem is necessary. Previous studies on honey-containing products for the treatment of vaginal infections reported it to be safe and without serious side effects (besides non-compliance $(6 \%)$, soiling of underclothes $(17 \%)$, and local irritation $(1.2 \%))$ [98,99]. It is not advised to use honey-based products on patients with known allergy to honey, and future research should further investigate potential side effects.

\section{Study Design of a New Prospective Randomized Controlled Trial}

Several small studies recommend performing a study with a larger sample size, longer duration of treatment, and a longer follow-up $[95,96,98,99]$. A prospective randomized controlled trial to compare the efficacy of fluconazole (Diflucan ${ }^{\circledR}$ ) and an MGH formulation (L-Mesitran Soft ${ }^{\circledR}$ ) for the treatment of recurrent vulvovaginal candidiasis will start this year. The trial is registered on ClinicalTrials.gov (NCT04626258) and the Dutch National Clinical Trial database (NL 73974.000.21). The primary objective is to investigate the mycological cure of L-Mesitran Soft in relation to the current standard of care (fluconazole), 1 month after starting treatment in patients with RVVC, defined as at least one positive Candida culture and a minimum of three episodes of symptoms in one year. Since the number of relapses is important for investigating the long-term efficacy, the follow-up period will be 12 months. Secondary objectives are to investigate the effects on the clinical cure and symptoms, including redness, irritation, itching, dysuria, dyspareunia, and vaginal discharge. In addition, the prophylactic activity after 6 months of maintenance therapy and the number of relapses within 12 months will be investigated for long-term efficacy. Moreover, information about the side effects, discomfort, and quality of life will be collected and compared. Vaginal swabs will be collected at 1 month, 6 months, and 12 months after starting treatment. The patients will also fill in a questionnaire at inclusion and 1, 6, 9, and 12 months after the start of the therapy. The interventions are fluconazole (oral intake of $150 \mathrm{mg}$ capsules) at days 1, 4 and 7, followed by weekly intake for six months and L-Mesitran Soft (intravaginally $5 \mathrm{~g}$ with applicator) daily for 1 month, followed by weekly intravaginal application for the next 5 months. For fluconazole, this is the standard therapy regime [42]. For L-Mesitran Soft, a daily dosage of $5 \mathrm{~g} \mathrm{MGH}$ is frequently used in literature, as is also shown in Table $3[95-97,100]$.

\section{Rationale for Selecting the MGH-Based Formulation}

Many different types of honey exist, varying in composition and antimicrobial activity, e.g., due to floral composition and spatiotemporal differences. A limited number of MGHbased formulations that are CE- and FDA-approved exist (Medihoney, Activon, Manuka Fill, and L-Mesitran). Most of these products contain manuka honey, of which the main antimicrobial mechanism is based on methylglyoxal rather than hydrogen peroxide. We selected L-Mesitran for our study because this MGH-based formulation acts via hydrogen peroxide, and this may be more relevant for this indication. Moreover, several direct comparison studies show that other types of honey and L-Mesitran have stronger antimicrobial activity and enhanced efficacy against mucositis than manuka honey [103-107]. Moreover, L-Mesitran ointment has previously been used in a pilot study $(n=30)$ for the treatment 
of clinical vaginal infections, presenting a positive effect on the clinical and mycological cure [108].

The L-Mesitran Soft formulation consists of $40 \% \mathrm{MGH}$ and is supplemented with other ingredients: medical-grade lanolin, PEG4000, propylene glycol, and vitamins C and E. Multiple studies have directly compared L-Mesitran Soft with its raw honey component, including against different fungi (Malassezia pachydermatitis, Candida albicans, Candida glabrata, Candida krusei, Candida parapsilosis, and Candida auris) [79,103,109,110]. Interestingly, all of these studies showed that the complete formulation had a stronger antimicrobial activity when compared to the raw honey component $[79,103,109,110]$. MGH also demonstrated a synergistic activity with the other ingredients of L-Mesitran Soft on the inhibition and eradication of biofilms [104]. Moreover, L-Mesitran Soft is effective in treating chronic wounds infected with (multi-resistant) bacteria, even when present in biofilms [65,104,111]. There is extensive evidence of the antimicrobial and wound healing properties of L-Mesitran Soft in literature, and no negative side effects or safety issues have been reported $[65,68-71,104,111,112]$. This should ease the registration of the product for new indications, such as RVVC, when the trial is successful.

\section{Conclusions}

The population of women with RVVC is estimated to increase over the coming years. The most commonly used treatment for RVVC is fluconazole, which it seems will become inadequate in the future due to increasing resistance to fluconazole, the rise of NAC species, and the existence of biofilms. MGH might be a promising treatment in VVC and RVVC. In contrast to fluconazole, MGH is expected to have multiple beneficial mechanisms. In addition to the antifungal activity on Candida, MGH can likely also eliminate antifungalresistant Candida species, including NAC species, and eradicate biofilms. Moreover, MGH can modulate the microenvironment by its anti-inflammatory and antioxidative activity. In vitro studies and clinical studies demonstrated honey as a promising alternative therapy for RVVC. More research is needed to investigate the exact clinical efficacy and the longterm cure rate of $\mathrm{MGH}$; as proposed, this will be further investigated in a randomized controlled trial.

Author Contributions: S.J.J.M.v.R., C.M.J.G.L., G.J.O. and N.A.J.C. prepared the original draft manuscript and S.J.J.M.v.R. and N.A.J.C. reviewed and edited the manuscript. All authors have read and agreed to the published version of the manuscript.

Funding: This research received no external funding.

Informed Consent Statement: Not applicable.

Conflicts of Interest: The authors declare no conflict of interest.

\section{References}

1. Sobel, J.D. Recurrent vulvovaginal candidiasis. Am. J. Obstet. Gynecol. 2016, 214, 15-21. [CrossRef] [PubMed]

2. Denning, D.W.; Kneale, M.; Sobel, J.D.; Rautemaa-Richardson, R. Global burden of recurrent vulvovaginal candidiasis: A systematic review. Lancet Infect. Dis. 2018, 18, e339-e347. [CrossRef]

3. Sobel, J.D.; Wiesenfeld, H.C.; Martens, M.; Danna, P.; Hooton, T.M.; Rompalo, A.; Sperling, M.; Livengood, C., 3rd; Horowitz, B.; Von Thron, J.; et al. Maintenance fluconazole therapy for recurrent vulvovaginal candidiasis. N. Engl. J. Med. 2004, 351, 876-883. [CrossRef]

4. Rosati, D.; Bruno, M.; Jaeger, M.; Ten Oever, J.; Netea, M.G. Recurrent Vulvovaginal Candidiasis: An Immunological Perspective. Microorganisms 2020, 8, 144. [CrossRef] [PubMed]

5. Pappas, P.G.; Kauffman, C.A.; Andes, D.R.; Clancy, C.J.; Marr, K.A.; Ostrosky-Zeichner, L.; Reboli, A.C.; Schuster, M.G.; Vazquez, J.A.; Walsh, T.J.; et al. Clinical Practice Guideline for the Management of Candidiasis: 2016 Update by the Infectious Diseases Society of America. Clin. Infect. Dis. 2016, 62, e1-e50. [CrossRef]

6. Bauters, T.G.; Dhont, M.A.; Temmerman, M.I.; Nelis, H.J. Prevalence of vulvovaginal candidiasis and susceptibility to fluconazole in women. Am. J. Obstet. Gynecol. 2002, 187, 569-574. [CrossRef]

7. Banaeian-Borujeni, S.; Mobini, G.R.; Pourgheysari, B.; Validi, M. Comparison of the effect of honey and miconazole against Candida albicans in vitro. Adv. Biomed. Res. 2013, 2, 57. [CrossRef] 
8. Gardella, C.E.L.; Lentz, G.M. Comprehensive Gynecology; Lentz, G.L.R., Gershenson, D., Valea, F.A., Eds.; Elsevier: Philadelphia, PA, USA, 2012; Volume 7, pp. 524-565.

9. Workowski, K.A.; Bolan, G.A. Sexually transmitted diseases treatment guidelines, 2015. MMWR Recomm. Rep. Morb. Mortal. Wkly. Rep. Recomm. Rep. 2015, 64, 1-137.

10. Sobel, J.D.; Faro, S.; Force, R.W.; Foxman, B.; Ledger, W.J.; Nyirjesy, P.R.; Reed, B.D.; Summers, P.R. Vulvovaginal candidiasis: Epidemiologic, diagnostic, and therapeutic considerations. Am. J. Obstet. Gynecol. 1998, 178, 203-211. [CrossRef]

11. Lema, V.M. Recurrent Vulvo-Vaginal Candidiasis: Diagnostic and Management Challenges in a Developing Country Context. Obstet. Gynecol. Int. J. 2017, 7, 260. [CrossRef]

12. Schoch, C.L.; Seifert, K.A.; Huhndorf, S.; Robert, V.; Spouge, J.L.; Levesque, C.A.; Chen, W.; Fungal Barcoding, C.; Fungal Barcoding Consortium. Nuclear ribosomal internal transcribed spacer (ITS) region as a universal DNA barcode marker for Fungi. Proc. Natl. Acad. Sci. USA 2012, 109, 6241-6246. [CrossRef] [PubMed]

13. Patel, R. A Moldy Application of MALDI: MALDI-ToF Mass Spectrometry for Fungal Identification. J. Fungi 2019, 5, 4. [CrossRef] [PubMed]

14. Kennedy, M.A.; Sobel, J.D. Vulvovaginal Candidiasis Caused by Non-albicans Candida Species: New Insights. Curr. Infect. Dis. Rep. 2010, 12, 465-470. [CrossRef]

15. Makanjuola, O.; Bongomin, F.; Fayemiwo, S.A. An Update on the Roles of Non-albicans Candida Species in Vulvovaginitis. J. Fungi 2018, 4, 121. [CrossRef]

16. Donders, G.G.; Sobel, J.D. Candida vulvovaginitis: A store with a buttery and a show window. Mycoses 2017, 60, 70-72. [CrossRef] [PubMed]

17. Richardson, J.P.; Willems, H.M.E.; Moyes, D.L.; Shoaie, S.; Barker, K.S.; Tan, S.L.; Palmer, G.E.; Hube, B.; Naglik, J.R.; Peters, B.M. Candidalysin Drives Epithelial Signaling, Neutrophil Recruitment, and Immunopathology at the Vaginal Mucosa. Infect. Immun. 2018, 86, e00645-17. [CrossRef] [PubMed]

18. Ardizzoni, A.; Wheeler, R.T.; Pericolini, E. It Takes Two to Tango: How a Dysregulation of the Innate Immunity, Coupled With Candida Virulence, Triggers VVC Onset. Front. Microbiol. 2021, 12, 692491. [CrossRef]

19. Willems, H.M.E.; Ahmed, S.S.; Liu, J.; Xu, Z.; Peters, B.M. Vulvovaginal Candidiasis: A Current Understanding and Burning Questions. J. Fungi 2020, 6, 27. [CrossRef]

20. Cauchie, M.; Desmet, S.; Lagrou, K. Candida and its dual lifestyle as a commensal and a pathogen. Res. Microbiol. 2017, 168, 802-810. [CrossRef]

21. Mukaremera, L.; Lee, K.K.; Mora-Montes, H.M.; Gow, N.A.R. Candida albicans Yeast, Pseudohyphal, and Hyphal Morphogenesis Differentially Affects Immune Recognition. Front. Immunol. 2017, 8, 629. [CrossRef]

22. Calderone, R.A.; Fonzi, W.A. Virulence factors of Candida albicans. Trends Microbiol. 2001, 9, 327-335. [CrossRef]

23. Mayer, F.L.; Wilson, D.; Hube, B. Candida albicans pathogenicity mechanisms. Virulence 2013, 4, 119-128. [CrossRef] [PubMed]

24. Zangl, I.; Pap, I.J.; Aspock, C.; Schuller, C. The role of Lactobacillus species in the control of Candida via biotrophic interactions. Microb. Cell 2019, 7, 1-14. [CrossRef] [PubMed]

25. Moyes, D.L.; Wilson, D.; Richardson, J.P.; Mogavero, S.; Tang, S.X.; Wernecke, J.; Hofs, S.; Gratacap, R.L.; Robbins, J.; Runglall, M.; et al. Candidalysin is a fungal peptide toxin critical for mucosal infection. Nature 2016, 532, 64-68. [CrossRef] [PubMed]

26. Moyes, D.L.; Richardson, J.P.; Naglik, J.R. Candida albicans-epithelial interactions and pathogenicity mechanisms: Scratching the surface. Virulence 2015, 6, 338-346. [CrossRef] [PubMed]

27. Kalia, N.; Singh, J.; Kaur, M. Microbiota in vaginal health and pathogenesis of recurrent vulvovaginal infections: A critical review. Ann. Clin. Microbiol. Antimicrob. 2020, 19, 5. [CrossRef]

28. Fidel, P.L., Jr.; Barousse, M.; Espinosa, T.; Ficarra, M.; Sturtevant, J.; Martin, D.H.; Quayle, A.J.; Dunlap, K. An intravaginal live Candida challenge in humans leads to new hypotheses for the immunopathogenesis of vulvovaginal candidiasis. Infect. Immun. 2004, 72, 2939-2946. [CrossRef]

29. Wachtler, B.; Citiulo, F.; Jablonowski, N.; Forster, S.; Dalle, F.; Schaller, M.; Wilson, D.; Hube, B. Candida albicans-epithelial interactions: Dissecting the roles of active penetration, induced endocytosis and host factors on the infection process. PLoS ONE 2012, 7, e36952. [CrossRef]

30. Peters, B.M.; Palmer, G.E.; Nash, A.K.; Lilly, E.A.; Fidel, P.L., Jr.; Noverr, M.C. Fungal morphogenetic pathways are required for the hallmark inflammatory response during Candida albicans vaginitis. Infect. Immun. 2014, 82, 532-543. [CrossRef]

31. Re, A.C.S.; Martins, J.F.; Cunha-Filho, M.; Gelfuso, G.M.; Aires, C.P.; Gratieri, T. New perspectives on the topical management of recurrent candidiasis. Drug Deliv. Transl. Res. 2021, 11, 1568-1585. [CrossRef]

32. Sherry, L.; Kean, R.; McKloud, E.; O’Donnell, L.E.; Metcalfe, R.; Jones, B.L.; Ramage, G. Biofilms Formed by Isolates from Recurrent Vulvovaginal Candidiasis Patients Are Heterogeneous and Insensitive to Fluconazole. Antimicrob. Agents Chemother. 2017, 61, e01065-17. [CrossRef]

33. Muzny, C.A.; Schwebke, J.R. Biofilms: An Underappreciated Mechanism of Treatment Failure and Recurrence in Vaginal Infections. Clin. Infect. Dis. 2015, 61, 601-606. [CrossRef]

34. Gulati, M.; Nobile, C.J. Candida albicans biofilms: Development, regulation, and molecular mechanisms. Microbes Infect. 2016, 18, 310-321. [CrossRef]

35. Paiva, L.C.; Vidigal, P.G.; Donatti, L.; Svidzinski, T.I.; Consolaro, M.E. Assessment of in vitro biofilm formation by Candida species isolates from vulvovaginal candidiasis and ultrastructural characteristics. Micron 2012, 43, 497-502. [CrossRef] 
36. Harriott, M.M.; Lilly, E.A.; Rodriguez, T.E.; Fidel, P.L.; Noverr, M.C. Candida albicans forms biofilms on the vaginal mucosa. Microbiology 2010, 156, 3635-3644. [CrossRef] [PubMed]

37. Alves, C.T.; Silva, S.; Pereira, L.; Williams, D.W.; Azeredo, J.; Henriques, M. Effect of progesterone on Candida albicans vaginal pathogenicity. Int. J. Med. Microbiol. 2014, 304, 1011-1017. [CrossRef] [PubMed]

38. Sobel, J.D. Editorial Commentary: Vaginal Biofilm: Much Ado About Nothing, or a New Therapeutic Challenge? Clin. Infect. Dis. 2015, 61, 607-608. [CrossRef] [PubMed]

39. Valenti, P.; Rosa, L.; Capobianco, D.; Lepanto, M.S.; Schiavi, E.; Cutone, A.; Paesano, R.; Mastromarino, P. Role of Lactobacilli and Lactoferrin in the Mucosal Cervicovaginal Defense. Front. Immunol. 2018, 9, 376. [CrossRef] [PubMed]

40. Lykke, M.R.; Becher, N.; Haahr, T.; Boedtkjer, E.; Jensen, J.S.; Uldbjerg, N. Vaginal, Cervical and Uterine pH in Women with Normal and Abnormal Vaginal Microbiota. Pathogens 2021, 10, 90. [CrossRef] [PubMed]

41. Miller, E.A.; Beasley, D.E.; Dunn, R.R.; Archie, E.A. Lactobacilli Dominance and Vaginal pH: Why Is the Human Vaginal Microbiome Unique? Front. Microbiol. 2016, 7, 1936. [CrossRef] [PubMed]

42. Fluconazole 150mg Capsules. Available online: https://www.medicines.org.uk/emc/product/6086/smpc\#gref (accessed on 8 July 2021).

43. Whaley, S.G.; Berkow, E.L.; Rybak, J.M.; Nishimoto, A.T.; Barker, K.S.; Rogers, P.D. Azole Antifungal Resistance in Candida albicans and Emerging Non-albicans Candida Species. Front. Microbiol. 2016, 7, 2173. [CrossRef]

44. Zhang, Y.Q.; Gamarra, S.; Garcia-Effron, G.; Park, S.; Perlin, D.S.; Rao, R. Requirement for ergosterol in V-ATPase function underlies antifungal activity of azole drugs. PLoS Pathog. 2010, 6, e1000939. [CrossRef]

45. Rodrigues, M.L. The Multifunctional Fungal Ergosterol. mBio 2018, 9, e01755-18. [CrossRef]

46. Berkow, E.L.; Lockhart, S.R. Fluconazole resistance in Candida species: A current perspective. Infect. Drug Resist. 2017, 10, 237-245. [CrossRef]

47. Heimark, L.; Shipkova, P.; Greene, J.; Munayyer, H.; Yarosh-Tomaine, T.; DiDomenico, B.; Hare, R.; Pramanik, B.N. Mechanism of azole antifungal activity as determined by liquid chromatographic/mass spectrometric monitoring of ergosterol biosynthesis. J. Mass Spectrom. 2002, 37, 265-269. [CrossRef] [PubMed]

48. Marchaim, D.; Lemanek, L.; Bheemreddy, S.; Kaye, K.S.; Sobel, J.D. Fluconazole-resistant Candida albicans vulvovaginitis. Obstet. Gynecol. 2012, 120, 1407-1414. [CrossRef]

49. Badiee, P.; Alborzi, A. Susceptibility of clinical Candida species isolates to antifungal agents by E-test, Southern Iran: A five year study. Iran. J. Microbiol. 2011, 3, 183-188.

50. Citak, S.; Ozcelik, B.; Cesur, S.; Abbasoglu, U. In vitro susceptibility of Candida species isolated from blood culture to some antifungal agents. Jpn. J. Infect. Dis. 2005, 58, 44-46. [PubMed]

51. Saporiti, A.M.; Gomez, D.; Levalle, S.; Galeano, M.; Davel, G.; Vivot, W.; Rodero, L. Vaginal candidiasis: Etiology and sensitivity profile to antifungal agents in clinical use. Rev. Argent. Microbiol. 2001, 33, 217-222. [PubMed]

52. Tseng, Y.H.; Lee, W.T.; Kuo, T.C. In-Vitro Susceptibility of Fluconazole and Amphotericin B against Candida Isolates from Women with Vaginal Candidiasis in Taiwan. J. Food Drug Anal. 2005, 13, 12-16. [CrossRef]

53. Zhang, J.Y.; Liu, J.H.; Liu, F.D.; Xia, Y.H.; Wang, J.; Liu, X.; Zhang, Z.Q.; Zhu, N.; Yan, Y.; Ying, Y.; et al. Vulvovaginal candidiasis: Species distribution, fluconazole resistance and drug efflux pump gene overexpression. Mycoses 2014, 57, 584-591. [CrossRef] [PubMed]

54. Jackson, S.T.; Mullings, A.M.; Rainford, L.; Miller, A. The epidemiology of mycotic vulvovaginitis and the use of antifungal agents in suspected mycotic vulvovaginitis and its implications for clinical practice. West. Indian Med. J. 2005, 54, 192-195. [CrossRef] [PubMed]

55. Rodriguez-Cerdeira, C.; Martinez-Herrera, E.; Carnero-Gregorio, M.; Lopez-Barcenas, A.; Fabbrocini, G.; Fida, M.; El-Samahy, M.; Gonzalez-Cespon, J.L. Pathogenesis and Clinical Relevance of Candida Biofilms in Vulvovaginal Candidiasis. Front. Microbiol. 2020, 11, 544480. [CrossRef] [PubMed]

56. Taff, H.T.; Mitchell, K.F.; Edward, J.A.; Andes, D.R. Mechanisms of Candida biofilm drug resistance. Future Microbiol. 2013, 8, 1325-1337. [CrossRef]

57. Vediyappan, G.; Rossignol, T.; d'Enfert, C. Interaction of Candida albicans biofilms with antifungals: Transcriptional response and binding of antifungals to beta-glucans. Antimicrob. Agents Chemother. 2010, 54, 2096-2111. [CrossRef]

58. Hermanns, R.; Mateescu, C.; Thrasyvoulou, A.; Tananaki, C.; Wagener, F.A.D.T.G.; Cremers, N.A.J. Defining the standards for medical grade honey. J. Apic. Res. 2020, 59, 125-135. [CrossRef]

59. Yilmaz, A.C.; Aygin, D. Honey Dressing in Wound Treatment: A Systematic Review. Complement. Ther. Med. 2020, 51, 102388. [CrossRef] [PubMed]

60. Emineke, S.; Cooper, A.J.; Fouch, S.; Birch, B.R.; Lwaleed, B.A. Diluted honey inhibits biofilm formation: Potential application in urinary catheter management? J. Clin. Pathol. 2017, 70, 140-144. [CrossRef]

61. Aissat, S.; Ahmed, M.; Djebli, N. Propolis-Sahara honeys preparation exhibits antibacterial and anti-biofilm activity against bacterial biofilms formed on urinary catheters. Asian Pac. J. Trop. Dis. 2016, 6, 873-877. [CrossRef]

62. Fernandes, L.; Ribeiro, H.; Oliveira, A.; Sanches Silva, A.; Freitas, A.; Henriques, M.; Rodrigues, M.E. Portuguese honeys as antimicrobial agents against Candida species. J. Tradit. Complement. Med. 2021, 11, 130-136. [CrossRef]

63. Boukraa, L.; Benbarek, H.; Moussa, A. Synergistic action of starch and honey against Candida albicans in correlation with diastase number. Braz. J. Microbiol. 2008, 39, 40-43. [CrossRef] 
64. Mandal, M.D.; Mandal, S. Honey: Its medicinal property and antibacterial activity. Asian Pac. J. Trop. Biomed. 2011, 1, 154-160. [CrossRef]

65. Nair, H.K.R.; Tatavilis, N.; Pospisilova, I.; Kucerova, J.; Cremers, N.A.J. Medical-Grade Honey Kills Antibiotic-Resistant Bacteria and Prevents Amputation in Diabetics with Infected Ulcers: A Prospective Case Series. Antibiotics 2020, 9, 529. [CrossRef]

66. Blair, S.E.; Cokcetin, N.N.; Harry, E.J.; Carter, D.A. The unusual antibacterial activity of medical-grade Leptospermum honey: Antibacterial spectrum, resistance and transcriptome analysis. Eur. J. Clin. Microbiol. Infect. Dis. 2009, 28, 1199-1208. [CrossRef]

67. Koc, A.N.; Silici, S.; Ercal, B.D.; Kasap, F.; Hormet-Oz, H.T.; Mavus-Buldu, H. Antifungal activity of Turkish honey against Candida spp. and Trichosporon spp: An in vitro evaluation. Med. Mycol. 2009, 47, 707-712. [CrossRef] [PubMed]

68. Smaropoulos, E.; Cremers, N.A. Medical grade honey for the treatment of paediatric abdominal wounds: A case series. J. Wound Care 2020, 29, 94-99. [CrossRef] [PubMed]

69. Smaropoulos, E.; Cremers, N.A.J. The pro-healing effects of medical grade honey supported by a pediatric case series. Complement. Ther. Med. 2019, 45, 14-18. [CrossRef]

70. Smaropoulos, E.; Cremers, N.A.J. Medical grade honey for the treatment of extravasation-induced injuries in preterm neonatesA case series. Adv. Neonatal Care 2020, 21, 122-132. [CrossRef]

71. Smaropoulos, E.; Cremers, N.A.J. Treating severe wounds in pediatrics with medical grade honey: A case series. Clin. Case Rep. 2020, 8, 469-476. [CrossRef]

72. Fluconazole is a Triazole Antifungal Used to Treat Various Fungal Infections Including Candidiasis. Available online: https: //www.drugbank.ca/drugs/DB00196 (accessed on 26 April 2021).

73. Doke, S.K.; Raut, J.S.; Dhawale, S.; Karuppayil, S.M. Sensitization of Candida albicans biofilms to fluconazole by terpenoids of plant origin. J. Gen. Appl. Microbiol. 2014, 60, 163-168. [CrossRef] [PubMed]

74. Cavalheiro, M.; Teixeira, M.C. Candida Biofilms: Threats, Challenges, and Promising Strategies. Front. Med. 2018, 5, 28. [CrossRef]

75. Irish, J.; Carter, D.A.; Shokohi, T.; Blair, S.E. Honey has an antifungal effect against Candida species. Med. Mycol. 2006, 44, 289-291. [CrossRef] [PubMed]

76. Shokri, H.; Sharifzadeh, A. Fungicidal efficacy of various honeys against fluconazole-resistant Candida species isolated from HIV(+) patients with candidiasis. J. Mycol. Med. 2017, 27, 159-165. [CrossRef] [PubMed]

77. Ansari, M.J.; Al-Ghamdi, A.; Usmani, S.; Al-Waili, N.S.; Sharma, D.; Nuru, A.; Al-Attal, Y. Effect of jujube honey on Candida albicans growth and biofilm formation. Arch. Med. Res. 2013, 44, 352-360. [CrossRef] [PubMed]

78. Estevinho, M.L.; Afonso, S.E.; Feas, X. Antifungal effect of lavender honey against Candida albicans, Candida krusei and Cryptococcus neoformans. J. Food Sci. Technol. 2011, 48, 640-643. [CrossRef] [PubMed]

79. Hermanns, R.; Cremers, N.A.J.; Leeming, J.P.; van der Werf, E.T. Sweet Relief: Determining the Antimicrobial Activity of Medical Grade Honey Against Vaginal Isolates of Candida albicans. J. Fungi 2019, 5, 85. [CrossRef]

80. Al-Waili, N.S. Mixture of honey, beeswax and olive oil inhibits growth of Staphylococcus aureus and Candida albicans. Arch. Med. Res. 2005, 36, 10-13. [CrossRef]

81. Khosravi, A.R.; Shokri, H.; Katiraee, F.; Ziglari, T.; Forsi, M. Fungicidal potential of different Iranian honeys against some pathogenic Candida species. J. Apic. Res. 2008, 47, 256-260. [CrossRef]

82. Deorukhkar, S.C.; Saini, S.; Mathew, S. Non-albicans Candida Infection: An Emerging Threat. Interdiscip. Perspect. Infect. Dis. 2014, 2014, 615958. [CrossRef]

83. Shamala, T.R.; Shri Jyothi, Y.; Saibaba, P. Stimulatory effect of honey on multiplication of lactic acid bacteria under in vitro and in vivo conditions. Lett. Appl. Microbiol. 2000, 30, 453-455. [CrossRef]

84. Samarghandian, S.; Farkhondeh, T.; Samini, F. Honey and Health: A Review of Recent Clinical Research. Pharmacogn. Res. 2017, 9, 121-127. [CrossRef]

85. Vallianou, N.; Gounari, P.; Skourtis, A.; Panagos, J.; Kazazis, C. Honey and its Anti-Inflammatory, Anti-Bacterial and Anti-Oxidant Properties. Gen. Med. Open Access 2014, 2, 132-137. [CrossRef]

86. Yaghoobi, R.; Kazerouni, A.; Kazerouni, O. Evidence for Clinical Use of Honey in Wound Healing as an Anti-bacterial, Antiinflammatory Anti-oxidant and Anti-viral Agent: A Review. Jundishapur J. Nat. Pharm. Prod. 2013, 8, 100-104. [CrossRef] [PubMed]

87. Bogdanov, S.; Jurendic, T.; Sieber, R.; Gallmann, P. Honey for nutrition and health: A review. J. Am. Coll. Nutr. 2008, 27, 677-689. [CrossRef] [PubMed]

88. Vaday, G.G.; Franitza, S.; Schor, H.; Hecht, I.; Brill, A.; Cahalon, L.; Hershkoviz, R.; Lider, O. Combinatorial signals by inflammatory cytokines and chemokines mediate leukocyte interactions with extracellular matrix. J. Leukoc. Biol. 2001, 69, 885-892. [PubMed]

89. Sokol, C.L.; Luster, A.D. The chemokine system in innate immunity. Cold Spring Harb. Perspect. Biol. 2015, 7. [CrossRef] [PubMed]

90. Miguel, M.G.; Antunes, M.D.; Faleiro, M.L. Honey as a Complementary Medicine. Integr. Med. Insights 2017, 12, 1178633717702869. [CrossRef] [PubMed]

91. Gasparrini, M.; Afrin, S.; Forbes-Hernandez, T.Y.; Cianciosi, D.; Reboredo-Rodriguez, P.; Amici, A.; Battino, M.; Giampieri, F. Protective effects of Manuka honey on LPS-treated RAW 264.7 macrophages. Part 2: Control of oxidative stress induced damage, increase of antioxidant enzyme activities and attenuation of inflammation. Food Chem. Toxicol. 2018, 120, 578-587. [CrossRef]

92. Ahmad, A.; Khan, R.A.; Mesaik, M.A. Anti inflammatory effect of natural honey on bovine thrombin-induced oxidative burst in phagocytes. Phytother. Res. 2009, 23, 801-808. [CrossRef] 
93. Gustafsson, K.; Tatz, A.M.; Slavin, R.A.; Dahan, R.; Ahmad, W.A.; Sutton, G.A.; Kelmer, G. Will local intraoperative application of Medical Grade Honey in the incision protect against incisional infection in horses undergoing colic surgery? AAEP Proc. 2019, 65, 387-388.

94. Mandel, H.H.; Sutton, G.A.; Abu, E.; Kelmer, G. Intralesional application of medical grade honey improves healing of surgically treated lacerations in horses. Equine Vet. J. 2020, 52, 41-45. [CrossRef]

95. Banaeian, S.; Sereshti, M.; Rafieian, M.; Farahbod, F.; Kheiri, S. Comparison of vaginal ointment of honey and clotrimazole for treatment of vulvovaginal candidiasis: A random clinical trial. J. Mycol. Med. 2017, 27, 494-500. [CrossRef] [PubMed]

96. Seifinadergoli, Z.; Nahidi, F.; Safaiyan, A.; Javadzadeh, Y.; Eteraf-Oskouei, T. Comparison of the efficacy of honey gel and clotrimazole cream in the treatment of vaginal candidiasis symptoms: A randomized clinical trial. Electron. Physician 2018, 10, 6904-6911. [CrossRef] [PubMed]

97. Darvishi, M.; Jahdi, F.; Hamzegardeshi, Z.; Goodarzi, S.; Vahedi, M. The Comparison of vaginal cream of mixing yogurt, honey and clotrimazole on symptoms of vaginal candidiasis. Glob. J. Health Sci. 2015, 7, 108-116. [CrossRef]

98. Abdelmonem, A.M.; Rasheed, S.M.; Mohamed, A. Bee-honey and yogurt: A novel mixture for treating patients with vulvovaginal candidiasis during pregnancy. Arch. Gynecol. Obstet. 2012, 286, 109-114. [CrossRef]

99. Aboushady, R.M.N.; Eswi, A.; Mostafa, F.A.M. Sider Honey vs. Fluconazole and the Cure Rate of Vulvovaginal Candidiasis. IOSR J. Nurs. Health Sci. 2015, 4, 5-14. [CrossRef]

100. Jahdi, F.; Hamzehgardeshi, Z.; Kuolaei, M.D.; Vahedi, M.; Goodarzi, S. Vulvovaginal Candidiasis Symptom Reduction-Honey, Yogurt-and-Honey and Clotrimazole Vaginal Cream-A Triple Blind Randomized Control Trial. J. Evol. Med. Dent. Sci. 2021, 10, 515-521. [CrossRef]

101. Rasooli, T.; Nahidi, F.; Mojab, F.; Nasiri, M.; Parsapour, H. Effect of Honey Cinnamon Vaginal Cream and Clotrimazole Vaginal Cream on Improvement of Candida Vaginitis Symptoms in Women: Randomized Clinical Trial. Iran. J. Obstet. Gynecol. Infertil. 2019, 22, 59-67. [CrossRef]

102. Fazel, N.; Hashemian, M.; Ramezani, M.; Akaberi, A. Comparative Effect alone Honey and Mix with Chlotrimazol on Vaginitis Candidacies. Iran. J. Obstet. Gynecol. Infertil. 2012, 14, 48-54. [CrossRef]

103. Cremers, N.; Belas, A.; Santos Costa, S.; Couto, I.; de Rooster, H.; Pomba, C. In vitro antimicrobial efficacy of two medical grade honey formulations against common high-risk meticillin-resistant staphylococci and Pseudomonas spp. pathogens. Vet. Dermatol. 2020, 31, 90-96. [CrossRef] [PubMed]

104. Pleeging, C.C.F.; Coenye, T.; Mossialos, D.; De Rooster, H.; Chrysostomou, D.; Wagener, F.A.D.T.G.; Cremers, N.A.J. Synergistic Antimicrobial Activity of Supplemented Medical-Grade Honey against Pseudomonas aeruginosa Biofilm Formation and Eradication. Antibiotics 2020, 9, 866. [CrossRef] [PubMed]

105. Munstedt, K.; Momm, F.; Hubner, J. Honey in the management of side effects of radiotherapy- or radio/chemotherapy-induced oral mucositis. A systematic review. Complement. Ther. Clin. Pract. 2019, 34, 145-152. [CrossRef] [PubMed]

106. Liu, T.M.; Luo, Y.W.; Tam, K.W.; Lin, C.C.; Huang, T.W. Prophylactic and therapeutic effects of honey on radiochemotherapyinduced mucositis: A meta-analysis of randomized controlled trials. Support. Care Cancer 2019, 27, 2361-2370. [CrossRef] [PubMed]

107. Yang, C.; Gong, G.; Jin, E.; Han, X.; Zhuo, Y.; Yang, S.; Song, B.; Zhang, Y.; Piao, C. Topical application of honey in the management of chemo/radiotherapy-induced oral mucositis: A systematic review and network meta-analysis. Int. J. Nurs. Stud. 2019, 89, 80-87. [CrossRef] [PubMed]

108. Boon, M.E. Honey proves attractive for vaginal use. Jaarversl. LCPL 2003, 32-39. Available online: http:/ / docplayer.net/43938553 -A4-honey-cream-proves-attractive-for-vaginal-use-the-vaginal-smear-as-a-test-3.html (accessed on 15 August 2004).

109. De Groot, T.; Janssen, T.; Faro, D.; Cremers, N.A.J.; Chowdhary, A.; Meis, J.F. Antifungal Activity of a Medical-Grade Honey Formulation against Candida auris. J. Fungi 2021, 7, 50. [CrossRef] [PubMed]

110. Oliveira, A.M.P.; Devesa, J.S.P.; Hill, P.B. In vitro efficacy of a honey-based gel against canine clinical isolates of Staphylococcus pseudintermedius and Malassezia pachydermatis. Vet. Dermatol. 2018, 29, 180-e65. [CrossRef]

111. Holubová, A.; Chlupácová, L.; Cetlová, L.; Cremers, N.A.J.; Pokorná, A. Medical-Grade Honey as an Alternative Treatment for Antibiotics in Non-Healing Wounds-A Prospective Case Series. Antibiotics 2021, 10, 918. [CrossRef]

112. Zbuchea, A. Honey, Food and Medicine: Scientific Rationale and Practical Efficiency in External Administration of Medicinal Honey for Wound Healing. J. Agric. Sci. Technol. B 2017, 7, 206-219. [CrossRef] 